Cite this: Analyst, 2013, 138, 3792

Received 7th December 2012

Accepted 3rd May 2013

DOI: $10.1039 / c 3 a n 36817 c$

www.rsc.org/analyst

\section{Profiling intact steroid sulfates and unconjugated steroids in biological fluids by liquid chromatography- tandem mass spectrometry (LC-MS-MS) $\dagger$}

\author{
Christina E. Galuska, ${ }^{a}$ Michaela F. Hartmann, ${ }^{\text {aa }}$ Alberto Sánchez-Guijo, ${ }^{a}$ \\ Katharina Bakhaus, ${ }^{b}$ Joachim Geyer, ${ }^{b}$ Gerhard Schuler, ${ }^{c}$ Klaus-Peter Zimmer $^{a}$ \\ and Stefan A. Wudy ${ }^{\mathrm{a}}$
}

Within the combined DFG research project "Sulfated Steroids in Reproduction" an analytical method was needed for determining sulfated and unconjugated steroids with highest specificity out of different biological matrices such as aqueous solution, cell lysate and serum. With regard to this analytical challenge, LC-MS-MS presents the technique of choice because it permits (1) analysis of the intact steroid conjugate, (2) allows for simultaneous determination of multiple analytes (profiling, targeted metabolomics approach) and (3) is independent of phenomena such as cross-reactivity. Sample work up consisted of incubation of sample with internal standards (deuterium labeled steroids) followed by solid phase extraction. Only serum samples required a protein precipitation step prior to solid phase extraction. The extract was divided in two parts: six steroid sulfates (E1S, E2S, AS, 16-OH-DHEAS, PREGS, DHEAS) were analyzed by C18aQ-ESI-MS-MS in negative ion mode and eleven unconjugated steroids (E3, 16-OH-DHEA, E1, E2, ${ }^{4}$ A, DHEA, T, 17-OH-PREG, Prog, An, PREG) were analyzed by C18-APCI-MS-MS in positive ion mode. For steroid sulfates, we found high sensitivities with LoQ values ranging from 0.08 to $1 \mathrm{ng} \mathrm{mL}^{-1}$. Unconjugated steroids showed LoQ values between 0.5 and $10 \mathrm{ng} \mathrm{mL}^{-1}$. Calibration plots showed excellent linearity. Mean intra- and inter-assay CVs were $2.4 \%$ for steroid sulfates and $6.4 \%$ for unconjugated steroids. Accuracy - determined in a two-level spike experiment - showed mean relative errors of $5.9 \%$ for steroid sulfates and $6.1 \%$ for unconjugated steroids. In summary, we describe a novel LC-MS-MS procedure capable of profiling six steroid sulfates and eleven unconjugated steroids from various biological matrices.

\section{Introduction}

Up to now steroid sulfates have so far been considered as biologically inactive metabolites intended for elimination. According to the classical dogma, to initiate a biological response, steroid hormones must be available in an unbound, free form in order to pass the cell membrane and to interact with the respective receptor. However, the biological significance and the crucial role of steroid sulfates in physiological systems is now beginning to be more and more recognized.,

${ }^{a}$ Steroid Research \& Mass Spectrometry Unit, Division of Pediatric Endocrinology \& Diabetlogy, Center of Child and Adolescent Medicine, Justus-Liebig-University, Feulgenstrasse 12, 35392 Giessen, Germany. E-mail: Michaela.Hartmann@ uni-giessen.de

${ }^{b}$ Institute of Pharmacology and Toxicology, Justus-Liebig-University, Biomedical Research Center (BFS), Schubertstrasse 81, 35392 Giessen, Germany

${ }^{c}$ Clinic for Obstetrics, Gynecology and Andrology of Large and Small Animals, JustusLiebig-University, Frankfurter Strasse 106, Giessen, Germany

$\dagger$ Electronic supplementary information (ESI) available: Two tables showing intraand interassay precision for sulfated as well as unconjugated steroids. See DOI: $10.1039 / \mathrm{c} 3 \mathrm{an} 36817 \mathrm{c}$
During the last decades there was increasing evidence that hydrolysis of steroid sulfates catalyzed by steroid sulfatase is an important alternative source of precursors for the local supply of estrogens and androgens.,4 Estrogen receptor, steroid sulfatase and estrogen sulfotransferase were found to be intracellularly co-localized in the same tissue., ${ }^{5,6}$ Since the existence of such a system would also require penetration of steroid sulfates through the plasma membrane of a target cell, the discovery of membrane uptake carriers such as the sodiumdependent organic anion transporter (SOAT), being highly substrate specific for steroid sulfates ${ }^{7}$ and being highly expressed in reproductive tissues such as testis and placenta ${ }^{8}$ further points to a biological role of steroid sulfates. To elucidate the biological significance and the crucial role of steroid sulfates, the Deutsche Forschungsgemeinschaft (DFG) has funded a combined interdisciplinary research group (DFG Research Group 1369) to study the role of steroid sulfates in reproductive processes. Steroid determination with highest reliability from various biological matrices such as aqueous solution, cell lysate and serum was a prerequisite for the realization of this research project. Analytical methods based on 
mass spectrometry (MS) currently present the most specific qualitative and quantitative methods for steroid determination. ${ }^{9}$ In contrast to immunoassays, they do not suffer from analytical quality issues, e.g. poor specificity due to lack of antibody specificity. Furthermore, individual immunoassays only allow determination of a single steroid at a time. Combination of MS with a chromatographic technique such as gas chromatography (GC) or liquid chromatography (LC) allows for the metabolomics approach. However, only volatile and thermally stable steroids can be analyzed by GC-MS. ${ }^{\mathbf{1 0 , 1 1}}$ This precludes the direct analysis of intact steroid conjugates and requires hydrolysis or solvolysis. ${ }^{12,13}$ The development of "soft", i.e. non-disintegrating ionization techniques, opened new avenues for the analysis of complex biomolecules. Nowadays, electrospray ionization (ESI) and atmospheric pressure chemical ionization (APCI) are the most widely applied soft ionization techniques. Introduction of tandem mass spectrometry (MS-MS) represented a further breakthrough in LC-MS since this technique compensates for the rather poor chromatographic capacity of LC. Therefore, the LC-MS-MS approach currently presents the method of choice concerning the analysis of unconjugated and sulfated steroids. ${ }^{14,15}$ Presenting the analytical platform of the aforementioned DFG funded research group, our subproject's main objective consisted in developing an LC-MS-MS based method for the determination of six steroid sulfates representing important conjugates of sex hormones or their precursors. Furthermore, the LC-MS-MS analysis of eleven unconjugated steroids bearing importance in reproductive processes presented a second goal of our work. Our developments thus lay an analytical foundation not only for collaborators within our research group but also for all other scientists interested in using LC-MS-MS to unravel new mechanisms of steroid action in reproduction.

\section{Experimental}

\section{Materials}

Unlabeled as well as deuterium (d) labeled reference steroids such as estra-1,3,5(10)-trien-3-ol-17-one-3-sulfate (E1S), estra1,3,5(10)-trien-3,17 $\beta$-diol-3-sulfate (E2S), 5 -androsten-3 $\beta, 17 \beta$ diol-3-sulfate (AS), 5-androsten-3 $\beta, 16 \alpha$-diol-17-one-3-sulfate (16-OH-DHEAS), 5-pregnen-3 $\beta$-ol-20-one-3-sulfate (PREGS), 5 -androsten-3 $\beta$-ol-17-one-3-sulfate (DHEAS), estra-1,3,5(10)trien-3,16 $\alpha, 17 \beta$-triole (E3), 5-androsten-3 $\beta, 16 \alpha$-diol-17-one (16-OH-DHEA), estra-1,3,5(10)-trien-3-ol-17-one (E1), estra1,3,5(10)-trien-3,17 $\beta$-diol (E2), 4-androsten-3,17-dione $\left({ }^{4} \mathrm{~A}\right)$, 5 -androsten-3 $\beta$-ol-17-one (DHEA), 4-androsten-17 $\beta$-ol-3-one (T), 5-pregnen-3 $\beta, 17 \alpha$-diol-20-one (17-OH-PREG), 4-pregnen-3,20dione (Prog), $5 \alpha$-androstan-3 $\alpha$-ol-17-one (An), 5-pregnen-3 $\beta$-ol20-one (PREG), $\mathrm{d}_{4}$-E2S, $\mathrm{d}_{4}$-PREGS, $\mathrm{d}_{6}$-DHEAS, $\mathrm{d}_{3}$-E3, $\mathrm{d}_{3}$-cortisol, $\mathrm{d}_{7}-{ }^{4} \mathrm{~A}, \mathrm{~d}_{4}-\mathrm{E} 2, \mathrm{~d}_{3}-\mathrm{T}, \mathrm{d}_{3}-17-\mathrm{OH}-\mathrm{PREG}, \mathrm{d}_{9}$-Prog and $\mathrm{d}_{4}$-PREG were purchased from $\mathrm{C} / \mathrm{D} / \mathrm{N}$ Isotopes Inc. (Quebec, Canada), SigmaAldrich (Taufkirchen, Germany) and from Steraloids, (Inc., Newport, RI, USA). Ammonium hydroxide, formic acid and LCMS grade water were obtained from Fluka (Taufkirchen, Germany). Methanol and acetonitrile were of analytical grade and purchased from Merck (Darmstadt, Germany). Zinc sulfate heptahydrate was obtained from Roth (Karlsruhe, Germany). SepPak C18 (360 mg) and Oasis HLB (60 mg) columns were purchased from Waters Corporation (Milford, MA, USA). Chromabond C18ec (200 mg) cartridges were obtained from Macherey-Nagel (Düren, Germany).

\section{Preparation of standards, QC samples and study samples}

Stock solutions were prepared in methanol for each standard and each isotopic labeled internal standard (IS) at $250 \mu \mathrm{g} \mathrm{mL} \mathrm{m}^{-1}$, respectively. Working solutions were diluted in $20 \%$ methanol at a concentration level of $25 \mu \mathrm{g} \mathrm{mL}^{-1}$ and $2.5 \mu \mathrm{g} \mathrm{mL}^{-1} .100 \mathrm{~mL}$ of pooled human serum was incubated with $20 \mathrm{~g}$ activated charcoal for $48 \mathrm{~h}$ at $4{ }^{\circ} \mathrm{C}$ to strip the matrix of endogenous steroids. Mixtures were centrifuged at $14500 \times g$ for $60 \mathrm{~min}$, and supernatants were again centrifuged at $14500 \times g$ for $3 \times$ 30 min. HEK293 cells, stably transfected with $\mathrm{Na}^{+}$-Taurocholate Cotransporting Polypeptide (NTCP), were lyzed by 5 freeze-thaw cycles and centrifuged at $12000 \times g$. The cell lysates (diluted $1: 10)$ and the stripped serum were used for method evaluation and quality control in the respective biological matrix.

\section{Protein precipitation}

We tested different solvents for protein precipitation. $250 \mu \mathrm{L}$ of serum were treated with one of the following protein precipitation solutions: (A) $1 \mathrm{~mL}$ of acetonitrile, (B) $1 \mathrm{~mL}$ of methanolacetonitrile $1: 1(\mathrm{v} / \mathrm{v}),(\mathrm{C}) 500 \mu \mathrm{L}$ of methanol- $\mathrm{ZnSO}_{4}\left(89 \mathrm{~g} \mathrm{~L}^{-1}\right)$ $4: 1(\mathrm{v} / \mathrm{v})$, and (D) $500 \mu \mathrm{L}$ of acetonitrile- $\mathrm{ZnSO}_{4}\left(89 \mathrm{~g} \mathrm{~L}^{-1}\right) 4: 1$ $(\mathrm{v} / \mathrm{v})$. Then, the samples were vigorously mixed and centrifuged for $10 \mathrm{~min}$ at $14500 \times g$. The clear supernatants were evaporated under a stream of nitrogen and after redissolvement in $1 \mathrm{~mL}$ of water, they were transferred to an additional clean-up step using solid phase extraction.

\section{Solid phase extraction}

$1 \mathrm{~mL}$ of cell lysate and the pretreated serum samples were used to test the different SPE-materials, respectively: (I) Chromabond C18ec, (II) SepPak C18 and (III) Oasis HLB. SPE cartridges were successively conditioned with $5 \mathrm{~mL}$ of $\mathrm{MeOH}$ and $5 \mathrm{~mL}$ of water prior to use. After sample application and washing with $5 \mathrm{~mL}$ of water, steroids were eluted with $3 \mathrm{~mL}$ of methanol (I and II). For elution and separation of unconjugated and conjugated steroids Oasis HLB cartridges (III) were treated with $3 \mathrm{~mL}$ of ethylacetate (unconjugated steroids) and $3 \mathrm{~mL}$ of methanol (conjugated steroids). Eluates were dried under a stream of nitrogen. The fraction for ESI was dissolved in a mixture containing $89.95 \%$ water, $10 \%$ methanol and $0.05 \%$ ammonia. The fraction for APCI was diluted in a solvent system consisting of $79.9 \%$ water, $20 \%$ methanol and $0.1 \%$ formic acid.

\section{Final sample preparation protocol}

$250 \mu \mathrm{L}$ of serum, $250 \mu \mathrm{L}$ of cell lysate and $250 \mu \mathrm{L}$ of aqueous solution were spiked with a cocktail of internal standards. The cocktail contained $\mathrm{d}_{4}$-E2S, $\mathrm{d}_{4}$-PREGS, $\mathrm{d}_{6}$-DHEAS, $\mathrm{d}_{3}$-E3, $\mathrm{d}_{3}$-cortisol, $\mathrm{d}_{7}-{ }^{4} \mathrm{~A}, \mathrm{~d}_{4}-\mathrm{E} 2, \mathrm{~d}_{3}-\mathrm{T}, \mathrm{d}_{3}-17-\mathrm{OH}-\mathrm{PREG}, \mathrm{d}_{9}$-Prog and $\mathrm{d}_{4}$-PREG (5 ng per $\mathrm{mL}$ per $\mathrm{IS}$, respectively). After mixing 
vigorously, the samples were equilibrated with the internal standards for $60 \mathrm{~min}$ at room temperature under shaking. Serum samples were precipitated using acetonitrile- $\mathrm{ZnSO}_{4}\left(89 \mathrm{~g} \mathrm{~L}^{-1}, 4: 1\right.$ $(\mathrm{v} / \mathrm{v}))$ and further purified by solid phase extraction using SepPak C18. Cell lysates were directly transferred to Chromabond C18ec cartridges for purification. Since steroid sulfates were profiled using ESI and unconjugated steroids were profiled using APCI, samples were split in equal parts after extraction. The eluates or the aqueous solutions were dried under a stream of nitrogen. The fraction for ESI was dissolved in $220 \mu \mathrm{L}$ of a mixture containing $89.95 \%$ water, $10 \%$ methanol and $0.05 \%$ ammonia. The fraction for APCI was diluted in $220 \mu \mathrm{L}$ of a solvent system consisting of $79.9 \%$ water, $20 \%$ methanol and $0.1 \%$ formic acid (Scheme 1).

\section{HPLC conditions}

For chromatographic separation, an Agilent 1200SL HPLC system (Waldbronn, Germany) was used equipped with a Hypersil Gold aQ column $(50 \times 2.1 \mathrm{~mm}, 3 \mu \mathrm{m})$ and a Hypersil Gold column $(50 \times 2.1 \mathrm{~mm}, 5 \mu \mathrm{m})$, respectively (Thermo Fisher Scientific, Dreieich, Germany). LC-MS grade water (A1) and methanol (A2) were used as eluents at a flow rate of $0.5 \mathrm{~mL} \mathrm{~min}^{-1}$. Elution of steroid sulfates was performed on the Hypersil Gold aQ stationary phase using the following gradient: $\mathrm{T}_{0 \text { min }}=20 \%$ $(\mathrm{v} / \mathrm{v}) \mathrm{A} 2 ; \mathrm{T}_{1 \min }=37 \%(\mathrm{v} / \mathrm{v}) \mathrm{A} 2 ; \mathrm{T}_{2 \min }=41 \%(\mathrm{v} / \mathrm{v}) \mathrm{A} 2 ; \mathrm{T}_{3 \min }=$ $45 \%(\mathrm{v} / \mathrm{v}) \mathrm{A} 2 ; \mathrm{T}_{4 \min }=60 \%(\mathrm{v} / \mathrm{v}) \mathrm{A} 2 ; \mathrm{T}_{5 \min }=95 \%(\mathrm{v} / \mathrm{v}) \mathrm{A} 2 ; \mathrm{T}_{6-8 \min }=$ $20 \%(\mathrm{v} / \mathrm{v}) \mathrm{A} 2$. Elution of unconjugated steroids was performed on the Hypersil Gold stationary phase using the following gradient: $\mathrm{T}_{0 \min }=45 \%(\mathrm{v} / \mathrm{v}) \mathrm{A} 2 ; \mathrm{T}_{1.5 \min }=58 \%(\mathrm{v} / \mathrm{v}) \mathrm{A} 2 ; \mathrm{T}_{4.5 \min }=68 \%(\mathrm{v} / \mathrm{v})$ $\mathrm{A} 2 ; \mathrm{T}_{6.5 \mathrm{~min}}=98 \%(\mathrm{v} / \mathrm{v}) \mathrm{A} 2 ; \mathrm{T}_{8.5-9.5 \mathrm{~min}}=45 \%(\mathrm{v} / \mathrm{v}) \mathrm{A} 2 . \mathrm{A} 10 \mu \mathrm{L}$ portion was injected into the HPLC system, respectively.

\section{MS-MS parameters}

MS-MS analysis was carried out on a triple quadrupole mass spectrometer (TSQ, Quantum Ultra, Thermo Fisher Scientific,
Dreieich, Germany) with electrospray ionization (ESI) and atmospheric pressure chemical ionization (APCI) in the negative and positive ion mode. In the ESI negative mode - used for profiling steroid sulfates - the capillary temperature was $270{ }^{\circ} \mathrm{C}$ and the vaporizer temperature was $350^{\circ} \mathrm{C}$. Sheath gas was set at 50 arbitrary units, auxillary gas at 20 arbitrary units and high voltage at $3500 \mathrm{~V}$. In the APCI positive mode - used for profiling unconjugated steroids - the capillary temperature was $275{ }^{\circ} \mathrm{C}$ and the vaporizer temperature was $400{ }^{\circ} \mathrm{C}$. Sheath gas was set at 45 arbitrary units, auxillary gas at 5 arbitrary units and discharge current at $4.0 \mu \mathrm{A}$. Collision gas pressure was set at 1.5 mTorr. Calibration of the instrument was performed by infusion of a polytyrosine-mix solution. Multiple reaction monitoring transitions (MRM) for quantification of steroids were tuned and optimized by infusing each analyte and internal standard using a $25 \mu \mathrm{g} \mathrm{mL^{-1 }}$ solution in methanol via a syringe pump.

\section{Linearity}

To evaluate linearity ten-point calibration plots for the different analytes at concentrations between 0.08 and $250 \mathrm{ng}$ $\mathrm{mL}^{-1}$ were prepared in different matrices (aqueous solution, cell lysates and serum) in triplicate. To each sample, a cocktail containing the internal standards at fixed amounts of $5 \mathrm{ng}$ $\mathrm{mL}^{-1}$ each, were added. The peak area ratios of analyte and respective internal standard were plotted against the concentrations of analyte. A $1 / x$ weighting regression was chosen to ensure higher accuracy and precision at the low concentration end of the curve.

\section{Limit of detection/limit of quantification}

Sensitivity was measured by diluting the various analytes to various concentration levels in the different matrices. Signal to noise ratios were calculated and the limits of detection
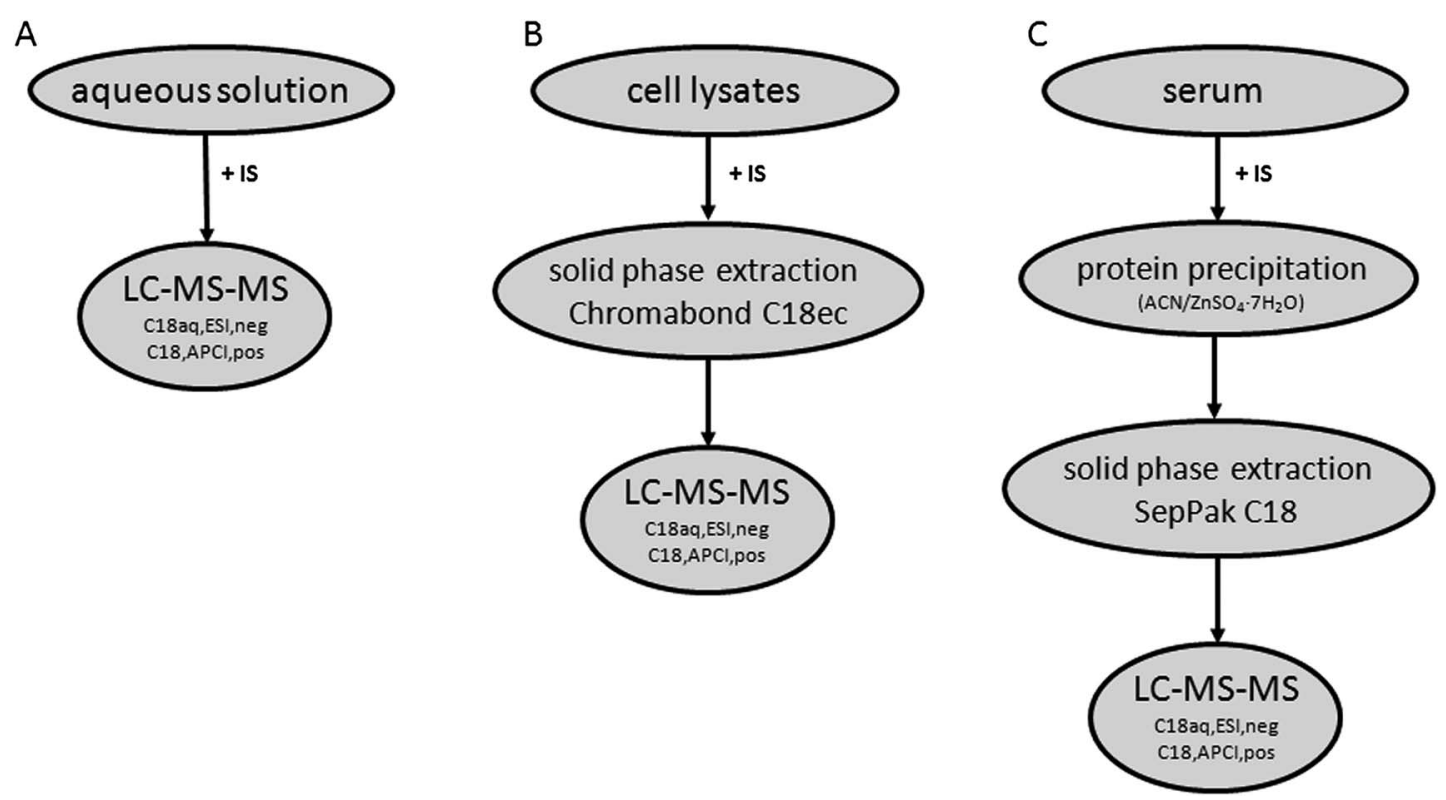

Scheme 1 Workflow for sample preparation of unconjugated steroids and steroid sulfates (A) in aqueous solution (B) in cell lysates and (C) in serum. 
(LoD)/quantification (LoQ) were determined. For the LoD we used a signal to noise ratio above 3 , for the LoQ a signal to noise ratio above 10 .

\section{Specificity/selectivity}

Analytes were identified by their chromatographic retention times and by monitoring specific mass transitions. Selectivity was examined by injection of the single analytes but measurement of the mass transitions of all analytes under consideration.

\section{Stability of IS and analytes}

Stability of steroids and IS was tested separately for the different biological matrices (serum, cell lysate, aqueous solution) and for two storage temperatures $\left(4{ }^{\circ} \mathrm{C}\right.$ and $\left.-20{ }^{\circ} \mathrm{C}\right)$. Samples were worked up after 1, 7, 30 and 90 days and compared with freshly prepared specimens.

\section{Intra-/interassay precision}

Evaluation of precision was performed by analysis of the analytes at two concentration levels in the different matrices and measured at five different occasions on one day and on five consecutive days. Precision was expressed as percent coefficient of variation.

\section{Spike experiments}

For determination of accuracy the different analytes were added to $5 \times 0.25 \mathrm{~mL}$ aliquots of the different matrices (serum, cell lysates, aqueous solution). Two different spike levels were made regarding each analyte. The samples were prepared as described previously. The results were interpreted as percent ratio between the amount calculated from the calibration curve and the theoretical amount.

\section{Recovery}

The recoveries of serum and cell lysate sample preparations were evaluated by comparing the response ratios of endogenous analyte/IS in purified aqueous standard solutions with the response ratios obtained in untreated standard solutions three times at three different concentration levels.

\section{Matrix effects}

The influence of ion suppression and ion enhancement was determined at one concentration level. Three samples were prepared for cell lysate and serum matrix, respectively. Matrix effects were then assessed by comparing the response ratios (A/IS) of the analytes spiked into the matrix with the response ratios (A/IS) of the analytes in aqueous standard solutions being purified in same manner.

Table 1 Ionization method, detected ions, masses and specific product ions of the analyzed steroids ${ }^{a}$

\begin{tabular}{|c|c|c|c|c|c|c|}
\hline Steroid & Ionization & Precursor & Ions $m / z$ & Product ions $\mathrm{m} / \mathrm{z}$ & $\begin{array}{l}\text { Collision } \\
\text { energy }[\mathrm{eV}]\end{array}$ & $\begin{array}{l}\text { Tube lens } \\
\text { voltages }[\mathrm{V}]\end{array}$ \\
\hline $\mathrm{d}_{4} \mathrm{E} 2 \mathrm{~S}^{*}$ & ESI, negative & {$[\mathrm{M}-\mathrm{H}]^{-}$} & 355.1 & 275.1 & 37 & 166 \\
\hline E1S & ESI, negative & {$[\mathrm{M}-\mathrm{H}]^{-}$} & 349.1 & 269.1 & 34 & 149 \\
\hline E2S & ESI, negative & {$[\mathrm{M}-\mathrm{H}]^{-}$} & 351.2 & 271.3 & 37 & 162 \\
\hline 16-OH-DHEAS & ESI, negative & {$[\mathrm{M}-\mathrm{H}]^{-}$} & 383.1 & 96.9 & 32 & 135 \\
\hline $\mathrm{d}_{6}$-DHEAS* & ESI, negative & {$[\mathrm{M}-\mathrm{H}]^{-}$} & 373.1 & 97.9 & 35 & 170 \\
\hline AS & ESI, negative & {$[\mathrm{M}-\mathrm{H}]^{-}$} & 369.1 & 96.9 & 37 & 169 \\
\hline DHEAS & ESI, negative & {$[\mathrm{M}-\mathrm{H}]^{-}$} & 367.1 & 96.9 & 30 & 141 \\
\hline $\mathrm{d}_{4}$-PREGS* & ESI, negative & {$[\mathrm{M}-\mathrm{H}]^{-}$} & 399.2 & 96.9 & 30 & 174 \\
\hline PREGS & ESI, negative & {$[\mathrm{M}-\mathrm{H}]^{-}$} & 395.1 & 96.9 & 32 & 181 \\
\hline $\mathrm{d}_{3}-\mathrm{E} 3 *$ & APCI, positive & {$\left[\mathrm{M}-\mathrm{H}_{2} \mathrm{O}+\mathrm{H}\right]^{+}$} & 274.2 & $134.9,158.9$ & 29,29 & 80 \\
\hline E3 & APCI, positive & {$\left[\mathrm{M}-\mathrm{H}_{2} \mathrm{O}+\mathrm{H}\right]^{+}$} & 271.2 & $133.0,159.0$ & 27,20 & 87 \\
\hline $\mathrm{d}_{3}$-cortisol $*$ & APCI, positive & {$[\mathrm{M}+\mathrm{H}]^{+}$} & 366.2 & $120.9,270.0$ & 32,20 & 100 \\
\hline 16-OH-DHEA & APCI, positive & {$\left[\mathrm{M}-2 \mathrm{H}_{2} \mathrm{O}+\mathrm{H}\right]^{+}$} & 269.2 & $91.0,105.0$ & 36,36 & 82 \\
\hline $\mathrm{d}_{4}-\mathrm{E} 2 *$ & APCI, positive & {$\left[\mathrm{M}-\mathrm{H}_{2} \mathrm{O}+\mathrm{H}\right]^{+}$} & 259.2 & $135.0,161.0$ & 21,20 & 90 \\
\hline E1 & APCI, positive & {$[\mathrm{M}+\mathrm{H}]^{+}$} & 271.1 & $133.0,159.0$ & 27,20 & 87 \\
\hline E2 & APCI, positive & {$\left[\mathrm{M}-\mathrm{H}_{2} \mathrm{O}+\mathrm{H}\right]^{+}$} & 255.1 & $132.9,159.0$ & 20,18 & 85 \\
\hline $\mathrm{d}_{7^{-}}{ }^{4} \mathrm{~A}^{*}$ & APCI, positive & {$[\mathrm{M}+\mathrm{H}]^{+}$} & 294.2 & $100.0,113.0$ & 20,20 & 118 \\
\hline${ }^{4} \mathrm{~A}$ & APCI, positive & {$[\mathrm{M}+\mathrm{H}]^{+}$} & 287.2 & $97.0,109.0$ & 19,23 & 103 \\
\hline $\mathrm{d}_{3} \mathrm{~T}^{*}$ & APCI, positive & {$[\mathrm{M}+\mathrm{H}]^{+}$} & 292.2 & $97.1,109.0$ & 29,32 & 94 \\
\hline DHEA & APCI, positive & {$\left[\mathrm{M}-\mathrm{H}_{2} \mathrm{O}+\mathrm{H}\right]^{+}$} & 271.2 & $197.1,213.1$ & 17,16 & 62 \\
\hline $\mathrm{T}$ & APCI, positive & {$[\mathrm{M}+\mathrm{H}]^{+}$} & 289.2 & $97.1,109.1$ & 20,31 & 98 \\
\hline $\mathrm{d}_{3}-17-\mathrm{OH}-\mathrm{PREG}{ }^{*}$ & APCI, positive & {$\left[\mathrm{M}-2 \mathrm{H}_{2} \mathrm{O}+\mathrm{H}\right]^{+}$} & 300.2 & $105.0,159.1$ & 37,23 & 83 \\
\hline 17-OH-PREG & APCI, positive & {$\left[\mathrm{M}-2 \mathrm{H}_{2} \mathrm{O}+\mathrm{H}\right]^{+}$} & 297.2 & $105.0,145.0$ & 38,30 & 102 \\
\hline $\mathrm{d}_{9}$-Prog* & APCI, positive & {$[\mathrm{M}+\mathrm{H}]^{+}$} & 324.3 & $100.0,113.0$ & 21,31 & 103 \\
\hline An & APCI, positive & {$\left[\mathrm{M}-\mathrm{H}_{2} \mathrm{O}+\mathrm{H}\right]^{+}$} & 273.2 & $161.1,199.1$ & 19,19 & 73 \\
\hline Prog & APCI, positive & {$[\mathrm{M}+\mathrm{H}]^{+}$} & 315.2 & $97.0,109.0$ & 21,33 & 87 \\
\hline $\mathrm{d}_{4}$-PREG ${ }^{*}$ & APCI, positive & {$\left[\mathrm{M}-\mathrm{H}_{2} \mathrm{O}+\mathrm{H}\right]^{+}$} & 303.2 & $104.9,130.9$ & 35,33 & 89 \\
\hline PREG & APCI, positive & {$\left[\mathrm{M}-\mathrm{H}_{2} \mathrm{O}+\mathrm{H}\right]^{+}$} & 299.2 & $130.9,158.9$ & 31,21 & 91 \\
\hline
\end{tabular}

${ }^{a}$ Internal standards are flagged with an asterisk $(*)$. All compounds that follow an internal standard are analyzed relative to that standard. 


\section{Results and discussion}

\section{Method development}

The aim of this study was to develop a LC-MS-MS method for profiling major steroid sulfates and unconjugated steroids to enable studies of their metabolism in various biological matrices and to elucidate their role in reproduction. Depending on the biological material we developed different sample preparation procedures. Purification of cell lysates was performed by solid phase extraction using Chromabond C18ec cartridges. Comparison of the MS results of the three tested SPE protocols Chromabond C18ec, SepPak C18 and Oasis HLB showed lowest background and therefore highest sensitivities for Chromabond C18ec. Additionally we could detect that separation of unconjugated and conjugated steroids by Oasis HLB SPE under the conditions used was not possible. Serum samples were prepared by protein precipitation with a $\mathrm{ZnSO}_{4}$ acetonitrile solution ${ }^{\mathbf{1 6 , 1 7}}$ followed by solid phase extraction with SepPak C18 cartridges. We investigated different protein precipitation protocols: (A) acetonitrile, (B) methanol-acetonitrile $1: 1(\mathrm{v} / \mathrm{v}),(\mathrm{C})$ methanol- $\mathrm{ZnSO}_{4}\left(89 \mathrm{~g} \mathrm{~L}^{-1}\right) 4: 1(\mathrm{v} / \mathrm{v})$ and (D) acetonitrile- $\mathrm{ZnSO}_{4}\left(89 \mathrm{~g} \mathrm{~L}^{-1}\right) 4: 1(\mathrm{v} / \mathrm{v}) .{ }^{16,18}$ The MS-data of protocol (C) and (D) exhibited the cleanest total ion chromatograms with lowest background. We chose protocol (D) because higher peak area amounts for the different steroids were detectable. In the following SPE clean up with the three mentioned materials we could again observe no separation of unconjugated and conjugated steroids using Oasis HLB. Purification by SepPakC18 material yielded best MS results. Steroid analogs labeled with stable isotopes (e.g. with deuterium or ${ }^{13} \mathrm{C}$ ) present ideally suited internal standards because they show practically the same chemical and chromatographic properties as the corresponding analytes. Therefore, they compensate for losses during sample preparation. With mass spectrometric detection they can easily be distinguished from their nonlabeled analogues. ${ }^{13} \mathrm{C}$ labeled compounds show high stability due to incorporation of the label into the carbon system of steroids, but their synthesis is extremely complex and expensive. A high enrichment of the label is difficult to achieve. Only a few unconjugated compounds are commercially available and they lack a high enrichment of the labels. So we decided to buy deuterium labeled steroids, which showed high isotope enrichments. However, not all commercially available deuterium labeled internal standards fulfilled the requirements for an isotope dilution LC-MS-MS method. Due to overlapping of internal standards with poor deuterium enrichment with the corresponding analytes, as well as deuterium loss of some labeled compounds, only suitable internal standards were integrated into our methods (Table 1). The best HPLC conditions for separating steroid sulfates in the shortest time possible was achieved on a C18aQ Hypersil column using a gradient from 20 to $95 \%$ methanol in $6 \mathrm{~min}$ at a flow rate of

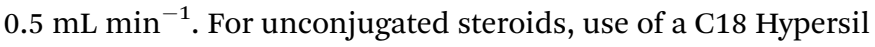
column with a gradient from 45 to $98 \%$ methanol in $8.5 \mathrm{~min}$ at a

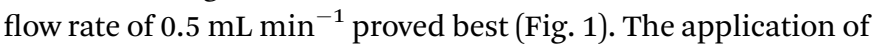
methanol-water mobile phases for analyzing both groups of steroids permitted a rapid change between methods and also contributed to achieving highest sensitivity for our analytes. The mass spectrometric properties of our different analytes were tested using APCI as well as ESI in negative and positive ionization mode. Additionally various ionization supporting additives were tested. Highest sensitivity was achieved by negative ionization ESI for steroid sulfates and by positive ionization APCI for unconjugated steroids. Ionization and consecutively the sensitivity could be enhanced by adding $0.05 \%$ ammonia for analyzing steroid sulfates and $0.1 \%$ formic acid for analyzing unconjugated steroids. Furthermore, multiple reaction monitoring (MRM), i.e. recording of specific precursor to fragment ions, additionally increases specificity and sensitivity of steroid measurement. For each analyte, as well as for the deuterated standards, MRM transitions, tube lens voltages, and collision energies were defined and optimized by
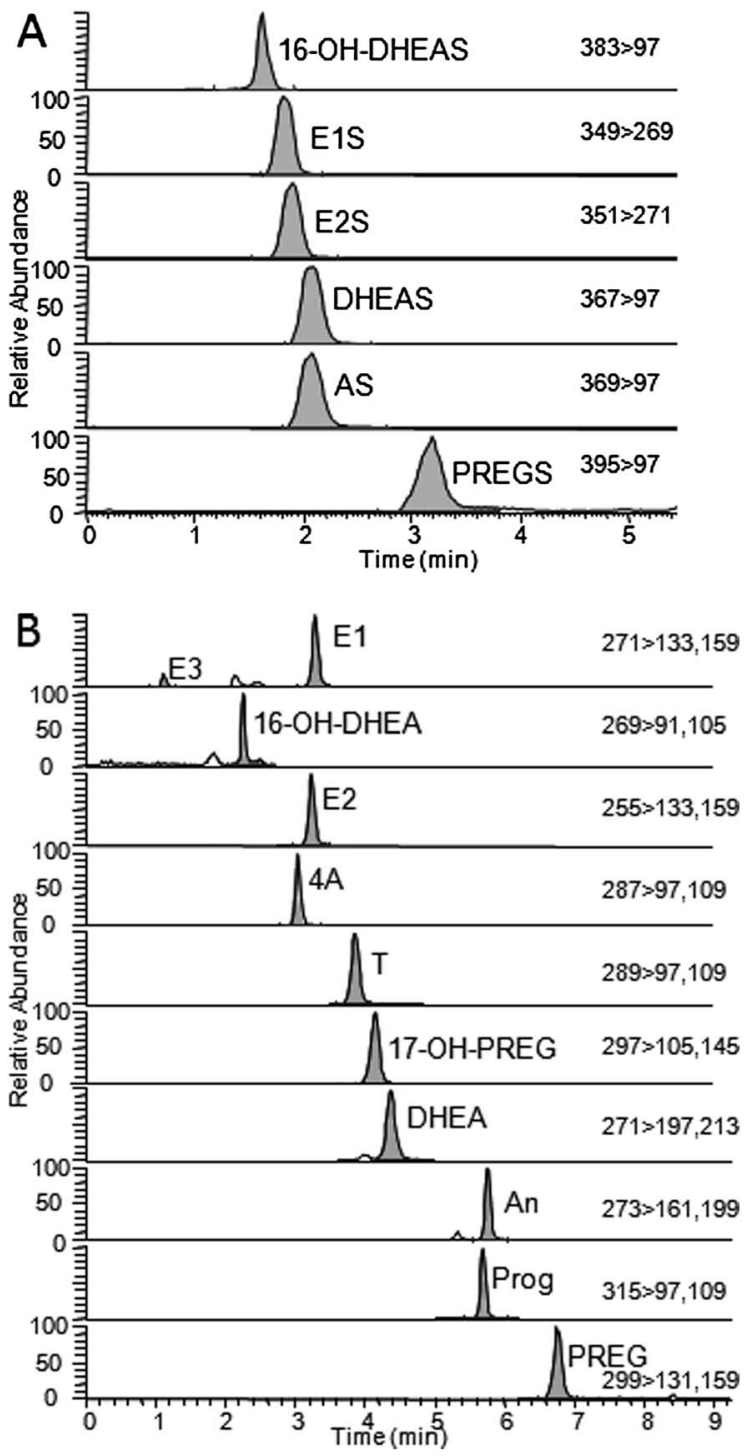

Fig. 1 MRM chromatogram of ID-LC-MS-MS analysis of a serum sample. The

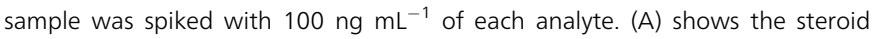
sulfates with their MRM transitions measured in the ESI negative ion mode; (B) shows the unconjugated steroids with their MRM transitions measured in APCI positive ion mode. 
direct infusion via the syringe pump (Table 1). All steroid sulfates were detected as deprotonated molecule ions $[\mathrm{M}-\mathrm{H}]^{-}$ in the full scan mass spectra. In the MS-MS experiments the dominating fragment ion was $\mathrm{m} / \mathrm{z} 97$ originating from the loss of the hydrogen sulfate group $\left[\mathrm{HSO}_{4}\right]^{-}$. Exceptions were E1S and E2S in which the sulfate is linked to the aromatic ring system, thus showing dominating signals with $m / z[\mathrm{M}-\mathrm{H}-80]^{-}$(loss of $\left.\mathrm{SO}_{3}\right) .{ }^{11}$ All other fragment ions were observed in a very low abundance and therefore we measured steroid sulfates only with a single mass transition. Most of the unconjugated steroids were detected as protonated adducts $[\mathrm{M}+\mathrm{H}]^{+}$in the full scan mass spectra. The two most abundant fragment ions yielded in the MS-MS experiments were used as mass transitions for the quantification of the unconjugated steroids (Table 1). Because E1 and E3 as well as T and DHEA shared the same mass transitions, chromatographic separation was essential for reliable determination of these analytes.

\section{Calibration plots/linearity}

In order to assess linearity of our method, ten-point calibration

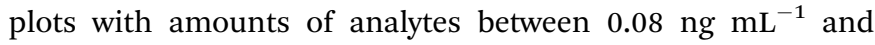
$250 \mathrm{ng} \mathrm{mL}{ }^{-1}$ containing fixed amounts $\left(5 \mathrm{ng} \mathrm{mL}^{-1}\right)$ of internal standards were prepared in triplicate in serum, cell lysate and aqueous solution and analyzed by LC-MS-MS. All calibration plots for steroid sulfates showed excellent linearity with coefficients of determination $\left(r^{2}\right)$ above 0.99 independent of the matrix used. For the unconjugated steroids we found values for $r^{2}$ above 0.99 in all matrices, except for E3, 16-OH-DHEA and 17-OH-PREG. The linear ranges as well as the corresponding coefficients of determination for the different analytes as determined in serum are shown in Table 2.

\section{Sensitivities}

The LoQ and LoD were assessed using Thermo Xcalibur 2.1 software (Thermo Fisher Scientific, Dreieich, Germany). LoQ values ranged between $0.08 \mathrm{ng} \mathrm{mL}^{-1}$ and $10 \mathrm{ng} \mathrm{mL}^{-1}$ depending on the analyte and the matrix of the sample. Table 2 summarizes the LoQ and LoD values determined in serum. In general, we found better LoQs and LoDs for sulfated than for unconjugated steroids. In matrices such as cell lysate or aqueous solution the LoQs/LoDs were on average two times better than in serum.

\section{Specificity/selectivity}

In all biological matrices, no significant interference from other steroids could be detected, neither amongst analytes and internal standards themselves.

\section{Stability}

Stability studies were performed for every single analyte and internal standard in different biological matrices at two different storage conditions at $4{ }^{\circ} \mathrm{C}$ and at $-20{ }^{\circ} \mathrm{C}$. After $1,7,30$ and 90 days the samples were worked up and measured against freshly prepared specimens. In aqueous solution, all steroid sulfates, three of the unconjugated steroids (E2, E3 and T) as well as the corresponding internal standards were stable for 90 days at $4{ }^{\circ} \mathrm{C}$. In serum, stability at $4{ }^{\circ} \mathrm{C}$ for 90 days could be shown for three of the steroid sulfates (DHEAS, AS and PREGS) and three of the unconjugated steroids (E3, E1 and T). However, all steroid sulfates, unconjugated steroids and deuterated steroids were found to be stable over 90 days at $-20{ }^{\circ} \mathrm{C}$ in aqueous solution. In serum, most of the analytes and internal standards demonstrated stability for 90 days at $-20^{\circ} \mathrm{C}$, with exception of $\mathrm{E} 3$ (stable for maximally 30 days at $-20{ }^{\circ} \mathrm{C}$ ), 16-OH-DHEA and 16-OHDHEAS (for which we observed degradation after 7 days even at $-20{ }^{\circ} \mathrm{C}$ ) (data not shown). Knowledge of sample stability is crucial for reliable sample procession and steroid determination. Most steroids in biological samples can be stored at $-20{ }^{\circ} \mathrm{C}$, but the reliable analysis of compounds such as 16-OH-DHEA or 16-OH-DHEAS requires immediate sample work up.

\section{Precision}

Precision represents reproducibility of repeated measurements. Results of intra- and inter-assay precision are given in Tables S-1, S-2a and b, ESI. $\dagger$ In summary, regarding steroid sulfates,

Table 2 Linear ranges, coefficients of determination and sensitivities of the analytes in steroid free serum. (a) Steroid sulfates and (b) unconjugated steroids ${ }^{a}$

(a) Steroid sulfates

\begin{tabular}{|c|c|c|c|c|c|c|}
\hline & E1S & E2S & 16-OH-DHEAS & AS & DHEAS & PREGS \\
\hline $\operatorname{lr}$ & $0.32-160$ & $0.08-75$ & $1-250$ & $1-250$ & $1-250$ & $0.5-250$ \\
\hline$r^{2}$ & 0.996 & 0.997 & 0.997 & 0.998 & 0.997 & 0.994 \\
\hline LoD & 1.5 & 0.8 & 5 & 5 & 2.5 & 5 \\
\hline LoQ & 0.4 & 0.08 & 1 & 1 & 1 & 0.5 \\
\hline
\end{tabular}

(b) Unconjugated steroids

\begin{tabular}{|c|c|c|c|c|c|c|c|c|c|c|c|}
\hline & E3 & 16-OH-DHEA & E1 & E2 & ${ }^{4} \mathrm{~A}$ & DHEA & $\mathrm{T}$ & 17-OH-PREG & An & Prog & PREG \\
\hline lr & $5-250$ & $10-250$ & $2.5-250$ & $1-250$ & $0.5-250$ & $2.5-250$ & $0.5-250$ & $10-250$ & $2.5-250$ & $2.5-250$ & $5-250$ \\
\hline$r^{2}$ & 0.922 & 0.958 & 0.994 & 0.995 & 0.998 & 0.998 & 0.999 & 0.978 & 0.991 & 0.996 & 0.991 \\
\hline LoD & 25 & 50 & 10 & 5 & 2.5 & 10 & 2.5 & 50 & 2 & 2 & 25 \\
\hline LoQ & 5 & 10 & 2.5 & 1 & 0.5 & 2.5 & 0.5 & 10 & 1 & 1 & 5 \\
\hline
\end{tabular}

${ }^{a} \mathrm{lr}$ : linear range in $\mathrm{ng} \mathrm{mL}^{-1}, r^{2}$ : coefficient of determination, LoD: in pg on column, LoQ: in $\mathrm{ng} \mathrm{mL}^{-1}$. 
intra-assay CVs showed very high precision ranging between 0.6\% (PREGS, aqueous solution) and 4.4\% (DHEAS, serum). Inter-assay CVs varied between $0.9 \%$ (E2S, cell lysate) and $6.7 \%$ (16-OH-DHEAS, serum). With respect to unconjugated steroids, CVs of intra- and interassay precision were less consistent depending on analyte and matrix. Intra-assay CVs ranged between $1.2 \%\left({ }^{4} \mathrm{~A}\right.$, cell lysate) and $15.8 \%(\mathrm{E} 3$, serum). Inter-assay CVs lay between $1.5 \%\left({ }^{4} \mathrm{~A}\right.$, aqueous solution) and $21.1 \%(16-\mathrm{OH}-$ DHEA, aqueous solution).

\section{Accuracy}

The accuracy of the method that describes the closeness of agreement between the true value and the value found, was determined by spike experiments. ${ }^{19}$ These were carried out for two spike levels in aqueous solution, cell lysate and serum. We could detect relative errors between -14\% (16-OH-DHEAS, spike-level 2, serum) and 15\% (16-OH-DHEAS, spike-level 1, cell lysate) for the steroid sulfates and -15\% (17-OH-PREG, spike level 1, aqueous solution) and $17 \%$ ( $\mathrm{T}$, spike level 1, serum) for the unconjugated steroids (Tables 3 and 4). Only minimal differences were found between the various matrices.

\section{Recovery}

The efficiency of sample preparation of cell lysates as well as serum was measured by comparison of untreated to purificated aqueous standard solutions. ${ }^{20}$ The recovery for sulfated steroids after lysate Chromabond $\mathrm{C} 18 \mathrm{ec}$ extraction ranged between $94.6 \%$ (16-OH-DHEAS) to $105.9 \%$ (16-OH-DHEAS), for unconjugated steroids between $80.2 \%$ (17-OH-PREG) to $112.2 \%$ (E3). The SepPak C18 extraction and additional protein precipitation as made for serum sample preparation showed recoveries for sulfated steroids between $90.0 \%$ (16-OH-DHEAS) and 109.8\% (16-OHDHEAS) and for unconjugated steroids between $88.0 \%$ (An) and $121.7 \%$ (17-OH-PREG). The recovery of almost all analytes showed a low relative error for the different concentration levels demonstrating consistent purification (Tables S-3, S-4a and b, ESI $\dagger$ ). Distinctions in the recoveries of the analyzed analytes can be traced back to the influence of the precipitation solution as well as to different adhesion behavior to the SPE-materials.

\section{Matrix effects}

Matrix effects on the ionization process were explored according to Matuszewski et $a .^{21}$ by comparing the response ratios of all analytes and their deuterated internal standards spiked into cell lysate and steroid free serum with the response ratios of these analytes and internal standards spiked into equally prepared aqueous solutions. The results of these experiments demonstrated no significant changes in the peak area ratios for the cell lysate matrix with respect to unconjugated and sulfated steroids (relative deviation -5.0 to $15.6 \%$ ), except PREG which showed an increase in the peak area and therefore enhancement in the ionization efficiency of $23.1 \%$. In serum we observed a higher variation in the peak area ratios of the different analytes versus the aqueous standard solutions (Tables S-5, S-6a and b, ESI $\dagger$ ). Values for the steroid sulfates ranged between -7.2 to $1.8 \%$ with the exception of 16-OH-DHEAS for which we detected a decrease
Table 3 Accuracy of the LC-MS-MS method for the steroid sulfates in aqueous solution, cell lysate and serum ${ }^{a}$

\begin{tabular}{|c|c|c|c|c|c|c|}
\hline & E1S & E2S & 16-OH-DHEAS & AS & DHEAS & PREGS \\
\hline \multicolumn{7}{|c|}{ In aqueous solution } \\
\hline Mean & 0 & 0 & 0 & 0 & 0 & 0 \\
\hline Spiked & 10.00 & 10.00 & 10.00 & 10.00 & 10.00 & 10.00 \\
\hline Exp. $\mathrm{m}$ & 10.00 & 10.00 & 10.00 & 10.00 & 10.00 & 10.00 \\
\hline Mean & 11.44 & 10.39 & 10.46 & 9.24 & 9.16 & 9.57 \\
\hline SD & 0.15 & 0.10 & 0.12 & 0.18 & 0.15 & 0.18 \\
\hline $\mathrm{CV}$ & 1.30 & 0.98 & 1.10 & 1.96 & 1.58 & 1.89 \\
\hline Rel. err & 14.4 & 3.9 & 4.6 & -7.6 & -8.4 & -4.3 \\
\hline Spiked & 100.00 & 100.00 & 100.00 & 100.00 & 100.00 & 100.00 \\
\hline Exp. m & 100.00 & 100.00 & 100.00 & 100.00 & 100.00 & 100.00 \\
\hline Mean & 95.83 & 95.86 & 93.88 & 98.41 & 98.91 & 100.46 \\
\hline SD & 3.60 & 3.12 & 4.01 & 1.64 & 2.45 & 4.61 \\
\hline CV & 3.76 & 3.26 & 4.27 & 1.67 & 2.47 & 4.58 \\
\hline Rel. err & -4.2 & -4.1 & -6.1 & -1.6 & -1.1 & 0.5 \\
\hline \multicolumn{7}{|c|}{ In cell lysate } \\
\hline Mean & 0 & 0 & 0 & 0 & 0 & 0 \\
\hline Spiked & 10.00 & 10.00 & 10.00 & 10.00 & 10.00 & 10.00 \\
\hline Exp. $\mathrm{m}$ & 10.00 & 10.00 & 10.00 & 10.00 & 10.00 & 10.00 \\
\hline Mean & 11.45 & 10.64 & 11.49 & 9.85 & 9.62 & 10.62 \\
\hline $\mathrm{SD}$ & 0.47 & 0.13 & 0.36 & 0.32 & 0.27 & 0.21 \\
\hline CV & 4.10 & 1.24 & 3.09 & 3.28 & 2.83 & 1.97 \\
\hline Rel. err & 14.5 & 6.4 & 14.9 & -1.5 & -3.8 & 6.2 \\
\hline Spiked & 100.00 & 100.00 & 100.00 & 100.00 & 100.00 & 100.00 \\
\hline Exp. $\mathrm{m}$ & 100.00 & 100.00 & 100.00 & 100.00 & 100.00 & 100.00 \\
\hline Mean & 105.40 & 102.25 & 97.01 & 102.10 & 101.83 & 104.44 \\
\hline SD & 5.37 & 0.81 & 5.05 & 2.30 & 1.87 & 3.15 \\
\hline $\mathrm{CV}$ & 5.09 & 0.79 & 5.20 & 2.26 & 1.84 & 3.01 \\
\hline Rel. err & 5.4 & 2.3 & -3.0 & 2.1 & 1.8 & 4.4 \\
\hline \multicolumn{7}{|c|}{ In serum } \\
\hline Mean & 0 & 0 & 0 & 0 & 1.02 & 0 \\
\hline Spiked & 10.00 & 10.00 & 10.00 & 10.00 & 10.00 & 10.00 \\
\hline Exp. $\mathrm{m}$ & 10.00 & 10.00 & 10.00 & 10.00 & 11.02 & 10.00 \\
\hline Mean & 11.10 & 11.18 & 11.01 & 10.21 & 9.68 & 10.69 \\
\hline SD & 0.44 & 0.22 & 1.22 & 0.39 & 0.30 & 0.23 \\
\hline $\mathrm{CV}$ & 3.96 & 2.01 & 11.09 & 3.84 & 3.05 & 2.16 \\
\hline Rel. err & 11.0 & 11.8 & 10.0 & 2.1 & -12.0 & 6.9 \\
\hline Spiked & 100.00 & 100.00 & 100.00 & 100.00 & 100.00 & 100.00 \\
\hline Exp. $m$ & 100.00 & 100.00 & 100.00 & 100.00 & 101.02 & 100.00 \\
\hline Mean & 100.46 & 101.66 & 86.22 & 96.04 & 97.93 & 109.11 \\
\hline SD & 2.43 & 2.21 & 3.93 & 5.51 & 5.47 & 7.77 \\
\hline $\mathrm{CV}$ & 2.42 & 2.17 & 4.56 & 5.74 & 5.58 & 7.12 \\
\hline Rel. err & 0.5 & 1.7 & -13.8 & -4.0 & -3.1 & 9.1 \\
\hline
\end{tabular}

${ }^{a}$ Spiked: spiked concentration in $\mathrm{ng} \mathrm{mL}^{-1}$, exp. m: expected mean in $\mathrm{ng}$ $\mathrm{mL}^{-1}$, mean: measured mean in $\mathrm{ng} \mathrm{mL}^{-1}, \mathrm{CV}$ in $\%$, rel. err: relative error in $\%, n=5$.

in the peak area ratio of $37.3 \%$. Peak area ratios of the unconjugated steroids lay between -11.5 to $1.9 \%$. However E3 showed a decrease of $43.6 \%$, and $17-\mathrm{OH}-\mathrm{PREG}$ an increase of $21.5 \%$. The deviation in the peak area ratios displayed a dramatical ion suppression for 16-OH-DHEAS and E3 as well as an ion enhancement for 17-OH-PREG in serum. These effects are due to coeluting matrix components which influence the ionization process. There are different possibilities to get rid of these matrix components, e.g. by changing the sample preparation procedures, or the chromatographic separation of the analytes which would certainly lead to extended analytical run times and matrix 
Table 4 Accuracy of the LC-MS-MS method for the unconjugated steroids in aqueous solution, cell lysate and serum ${ }^{a}$

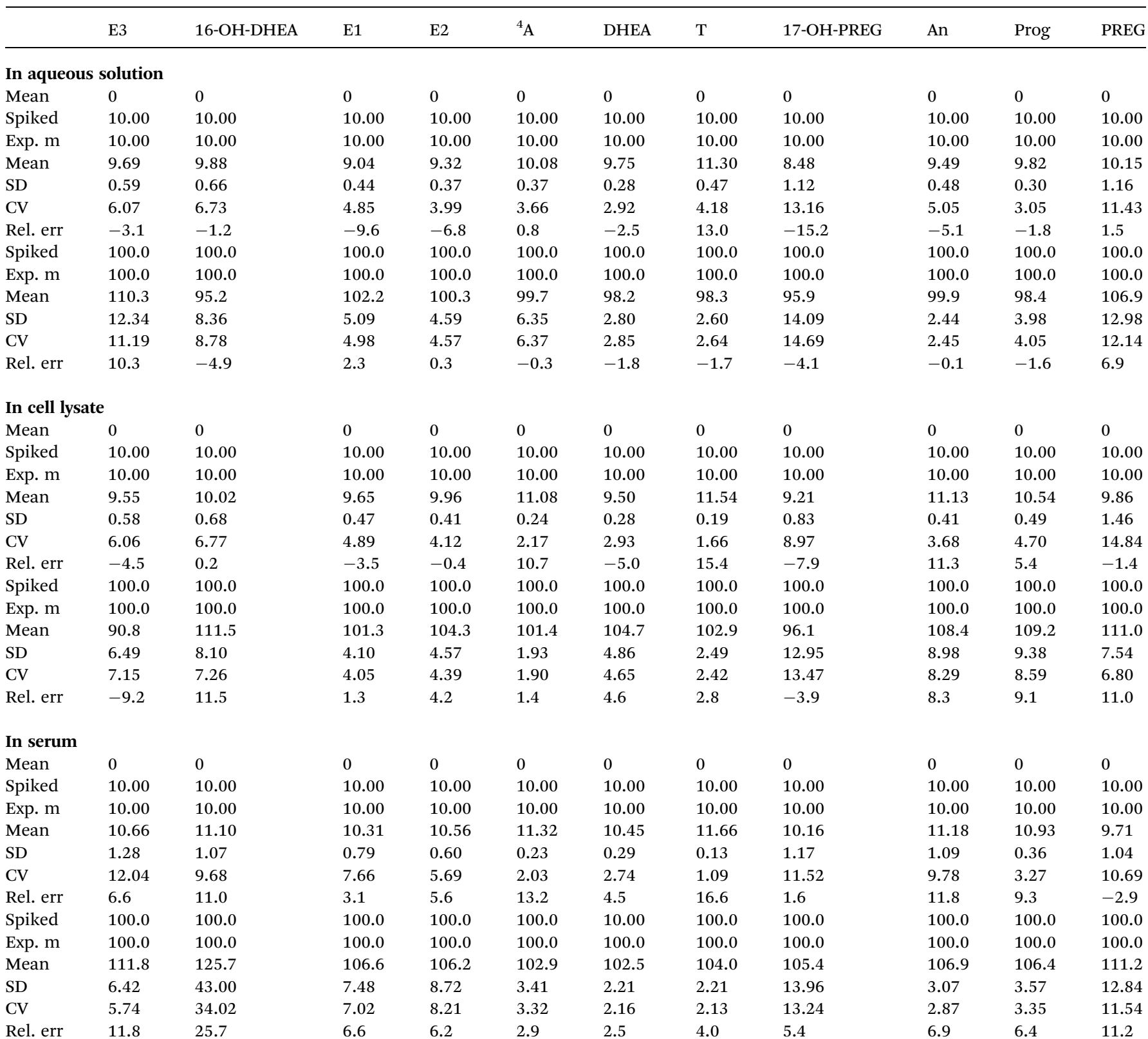

${ }^{a}$ Spiked: spiked concentration in $\mathrm{ng} \mathrm{mL}^{-1}$, exp. $\mathrm{m}$ : expected mean in $\mathrm{ng} \mathrm{mL}^{-1}$, mean: measured mean in ng $\mathrm{mL}^{-1}$, $\mathrm{CV}_{\text {in }} \%$, rel. err: relative error in $\%, n=5$.

effects on other analytes. ${ }^{17,21,22}$ Serum as well as lysate samples were always measured against their corresponding matrix calibration curves, which had been constructed under the same analytical conditions. Therefore accuracy of the analysis should not be impaired. This could successfully be demonstrated by the performed spike experiments (Tables 3 and 4).

\section{Applicability}

We could show the applicability of our method by analyzing different samples contributed by our coworkers from studies on steroid metabolism and the role of steroid sulfates in reproduction. Fig. 2 shows the MRM chromatogram of a serum sample from a capsular vein of the testis of a boar. In Fig. 3 we show the example of a steroid sulfate transport experiment performed with stably NTCP-transfected HEK293 cells. These cells, known to be capable of transporting steroid sulfates into cells, were incubated with a mixture of $10 \mu \mathrm{M}$ E1S, DHEAS and PREGS each. The analysis of the cell lysates revealed E1S, DHEAS and PREGS proving successful transport of these sulfates into the cells. PREGS was transported in higher amounts than the other steroid sulfates.

\section{Analytes}

According to the clinical dogma, steroid sulfates have been generally considered as biologically inactive metabolites intended for elimination. ${ }^{2324}$ This explains why only a few single 
steroid sulfates have hitherto been studied by LC-MS-MS and the available literature is scarce. Mainly clinical LC-MS-MS methods for the determination of DHEAS together with several unconjugated steroids ${ }^{\mathbf{1 6 , 2 5}}$ have so far been described in serum. Compared to these, we could achieve an improved LoQ for this metabolite. No method for measuring 16-OH-DHEAS by LC-MSMS has so far been reported. It is important to note that our data showed a certain instability of this compound and thus immediate sample preparation and measurement is advised. The quantification of PREGS by LC-MS-MS has so far been lacking. ${ }^{26}$ Likewise there is only one report on the analysis of AS in serum by LC-MS, in which a LoD of $0.25 \mathrm{ng}$ per injection was reported. ${ }^{18}$ LC-MS-MS quantification of E1S and E2S has so far only been described in urine by Zhang and Henion, ${ }^{27}$ who reported LoQs at comparable levels. In the field of steroid analysis, the utility of LC-MS-MS has meanwhile been demonstrated by several groups foremost with respect to the clinical high throughput analysis of diagnostically important unconjugated steroids, since only simple sample preparation is required and instrumental run times are short. ${ }^{16,25,28-31}$ In our LC-MS-MS profile of unconjugated steroids, 16-OH-DHEA presents the compound, for which no LC-MS-MS assay has been hitherto described. Since hardly any information is found in the literature on the stability of steroids in biological samples, it is important to point out, that 16-hydroxylated steroids such as E3 and 16-OH-DHEA are labile and warrant immediate sample work up analysis.
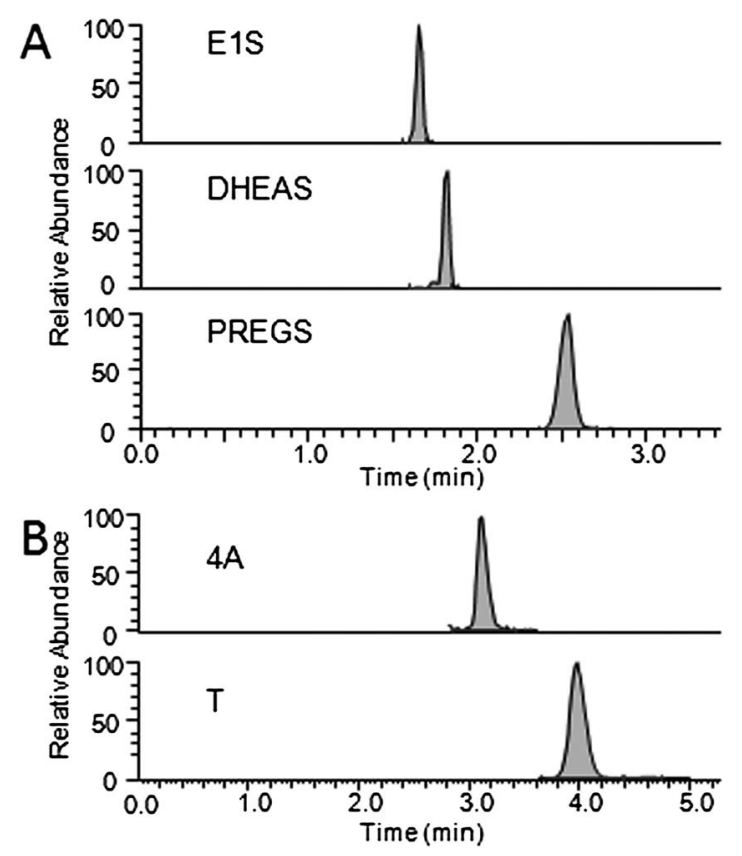

Fig. 2 MRM chromatogram of ID-LC-MS-MS analysis of serum from a capsular vein of the testis of a boar. (A) The concentrations of the requested steroid sulfates measured in ESI negative ion mode are: E1S: $71.5 \mathrm{ng} \mathrm{mL}^{-1}$, DHEAS: $85.9 \mathrm{ng} \mathrm{mL}^{-1}$, PREGS: $18.7 \mathrm{ng} \mathrm{mL}^{-1}$. (B) Unconjugated steroids were measured in $\mathrm{APCl}$ positive ion mode. The concentration of the requested steroids are: ${ }^{4} \mathrm{~A}: 8.1 \mathrm{ng} \mathrm{mL}-1, T$ : $119.2 \mathrm{ng} \mathrm{mL}^{-1}$.

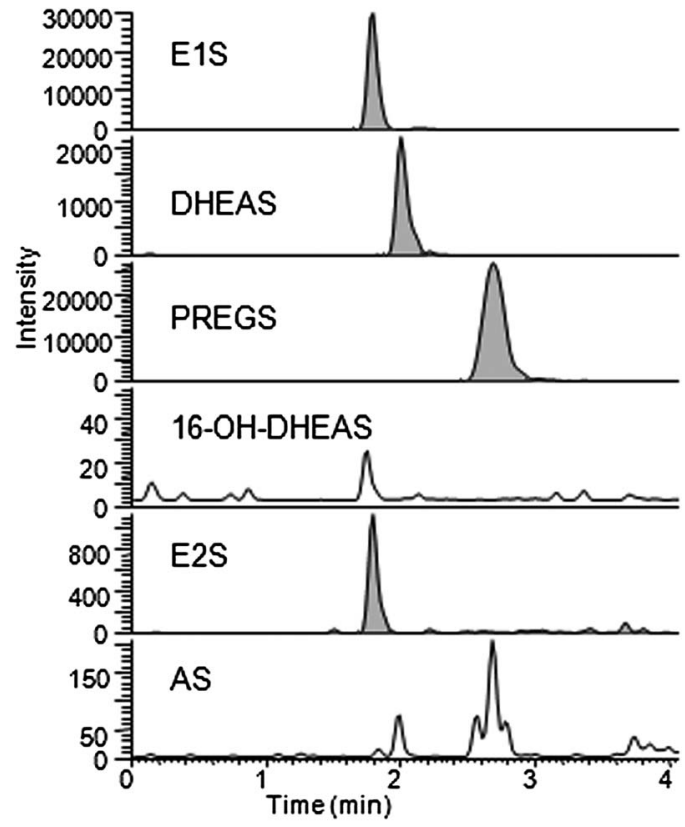

Fig. 3 MRM chromatogram of ID-LC-MS-MS transport study analysis of cell lysate of HEK 293 cells stably transfected with the steroid sulfate uptake carrier NTCP. Cells were incubated with a mixture of E1S, DHEAS and PREGS, $10 \mu \mathrm{M}$ each. The measured concentrations of the steroid sulfates were: E1S: $12.9 \mathrm{ng} \mathrm{mL}^{-1}$, DHEAS: $10.0 \mathrm{ng} \mathrm{mL}^{-1}$ and PREGS: $222.5 \mathrm{ng} \mathrm{mL}^{-1}$, indicating that NTCP transported all three compounds into the cells. E2S had a concentration of $8.8 \mathrm{ng}$ $\mathrm{mL}^{-1}, 16-\mathrm{OH}-\mathrm{DHEAS}$ and AS were not detectable.

\section{Conclusions}

We report on a new LC-MS-MS assay for profiling six sulfated and eleven unconjugated steroids out of different biological matrices including aqueous solutions, cell lysates and serum. The method consists of one sample preparation with solid phase extraction and if necessary protein precipitation prior to extraction. Then, the purified sample is divided in two parts for measuring the profile of six intact steroid sulfates in the ESI negative ion mode and the profile of eleven unconjugated steroids in the APCI positive ion mode. For the steroid sulfates we found high sensitivities with limit of quantifications $e . g$. in serum ranging from 0.08 to $1 \mathrm{ng} \mathrm{mL}^{-1}$. For the unconjugated steroids sensitivities varied more due to the nature of the analytes as has been reported from other authors, too. ${ }^{32}$ For these we found limits of quantifications in serum ranging from 0.5 to $10 \mathrm{ng} \mathrm{mL} \mathrm{m}^{-1}$. With the exception of E3, 16-OH-DHEA and 16-OHDHEAS, 14 out of 17 of the steroids were stable over 90 days at $-20{ }^{\circ} \mathrm{C}$ independent of the sample matrix. In case the aforementioned analytes are requested, we advise direct sample preparation and measurement of the samples. To the best of our knowledge, no LC-MS-MS method has been reported yet, allowing for the simultaneous determination of six steroid sulfates from various biological media. In our attempt to further characterize the biological function of steroid sulfates, our methodological developments provide the analytical basis for our collaborating research partners who will characterize transport, reactivation, and metabolism of steroid sulfates in biological systems. 


\section{Acknowledgements}

We gratefully acknowledge the expert technical assistance of Mrs Birgit Wardega. This work was funded by the Deutsche Forschungsgemeinschaft Research Group "Sulfated steroids in Reproduction" (DFG 1369), Subproject 7 "Determination of steroid sulfates in biological samples by liquid chromatography-tandem mass spectrometry" (Stefan A. Wudy, principal investigator).

\section{Notes and references}

1 C. A. Strott, Endocr. Rev., 2002, 23, 703-732.

2 C. Noordam, V. Dhir, J. C. McNelis, F. Schlereth, N. A. Hanley, N. Krone, J. A. Smeitink, R. Smeets, F. C. Sweep, H. L. Claahsen-van der Grinten and W. Arlt, N. Engl. J. Med., 2009, 360, 2310-2318.

3 K. W. Selcer, H. Kabler, J. Sarap, Z. Xiao and P. K. Li, Steroids, 2002, 67, 821-826.

4 J. R. Pasqualini and G. S. Chetrite, J. Steroid Biochem. Mol. Biol., 2005, 93, 221-236.

5 G. Schuler, H. Greven, M. P. Kowalewski, B. Doring, G. R. Ozalp and B. Hoffmann, Exp. Clin. Endocrinol. Diabetes, 2008, 116, 429-436.

6 M. J. Reed, A. Purohit, L. W. Woo, S. P. Newman and B. V. Potter, Endocr. Rev., 2005, 26, 171-202.

7 J. Geyer, J. R. Godoy and E. Petzinger, Biochem. Biophys. Res. Commun., 2004, 316, 300-306.

8 J. Geyer, B. Doring, K. Meerkamp, B. Ugele, N. Bakhiya, C. F. Fernandes, J. R. Godoy, H. Glatt and E. Petzinger, J. Biol. Chem., 2007, 282, 19728-19741.

9 S. A. Wudy and M. F. Hartmann, Horm. Metab. Res., 2004, 36, 415-422.

10 S. A. Wudy, M. Hartmann and J. Homoki, Steroids, 2002, 67, 851-857.

11 S. Reddy, C. R. Iden and B. J. Brownawell, Anal. Chem., 2005, 77, 7032-7038.

12 K. A. Bean and J. D. Henion, J. Chromatogr., B: Biomed. Sci. Appl., 1997, 690, 65-75.

13 L. D. Bowers and Sanaullah, J. Chromatogr., B: Biomed. Sci. Appl., 1996, 687, 61-68.

14 S. J. Soldin and O. P. Soldin, Clin. Chem., 2009, 55, 10611066.
15 S. K. Grebe and R. J. Singh, Clin. Biochem. Rev., 2011, 32, 5-31.

16 U. Ceglarek, L. Kortz, A. Leichtle, G. M. Fiedler, J. Kratzsch and J. Thiery, Clin. Chim. Acta, 2009, 401, 114-118.

17 A. Van Eeckhaut, K. Lanckmans, S. Sarre, I. Smolders and Y. Michotte, J. Chromatogr., B: Anal. Technol. Biomed. Life Sci., 2009, 877, 2198-2207.

18 K. Mitamura, Y. Nagaoka, K. Shimada, S. Honma, M. Namiki, E. Koh and A. Mizokami, J. Chromatogr., B: Anal. Technol. Biomed. Life Sci., 2003, 796, 121-130.

19 P. Hoffmann, M. F. Hartmann, T. Remer, K. P. Zimmer and S. A. Wudy, Steroids, 2010, 75, 1067-1074.

20 F. Badoud, E. Grata, J. Boccard, D. Guillarme, J. L. Veuthey, S. Rudaz and M. Saugy, Anal. Bioanal. Chem., 2011, 400, 503516.

21 B. K. Matuszewski, M. L. Constanzer and C. M. Chavez-Eng, Anal. Chem., 2003, 75, 3019-3030.

22 I. Marchi, V. Viette, F. Badoud, M. Fathi, M. Saugy, S. Rudaz and J. L. Veuthey, J. Chromatogr., A, 2010, 1217, 4071-4078.

23 C. A. Strott, Endocr. Rev., 1996, 17, 670-697.

24 E. Chapman, M. D. Best, S. R. Hanson and C. H. Wong, Angew. Chem., Int. Ed., 2004, 43, 3526-3548.

25 T. Guo, R. L. Taylor, R. J. Singh and S. J. Soldin, Clin. Chim. Acta, 2006, 372, 76-82.

26 S. Liu, J. Sjovall and W. J. Griffiths, Anal. Chem., 2003, 75, 5835-5846.

27 H. Zhang and J. Henion, Anal. Chem., 1999, 71, 39553964.

28 M. Vogeser and K. G. Parhofer, Exp. Clin. Endocrinol. Diabetes, 2007, 115, 559-570.

29 X. Xu, L. K. Keefer, D. J. Waterhouse, J. E. Saavedra, T. D. Veenstra and R. G. Ziegler, Anal. Chem., 2004, 76, 5829-5836.

30 T. Koal, D. Schmiederer, H. Pham-Tuan, C. Rohring and M. Rauh, J. Steroid Biochem. Mol. Biol., 2012, 129, 129138.

31 Y. Nakamura, J. Rege, F. Satoh, R. Morimoto, M. R. Kennedy, C. N. Ahlem, S. Honma, H. Sasano and W. E. Rainey, Clin. Endocrinol., 2012, 76, 778-784.

32 S. E. Jantti, A. Tammimaki, H. Raattamaa, P. Piepponen, R. Kostiainen and R. A. Ketola, Anal. Chem., 2010, 82, 3168-3175. 